\title{
Ambient air pollution and asthma
}

\author{
To the Editor:
}

We read with great interest the recent article by CAI et al. [1] on the likely role of PM10 (particulate matter with aerodynamic diameter $\leqslant 10 \mu \mathrm{m}$ ) in the development of asthma in adults. This report is a significant contribution to the debate about how important air pollution by particulate matter might be in the pathogenesis of asthma. Moreover, it adds to the growing body of work that supports a role for particulate air pollutants in the development of allergic asthma, including in children [2-5], as well as in triggering exacerbations of asthma [6,7].

The authors note that the cross-sectional design of the study limits its value in terms of establishing causality. In experimental studies using animal models, and airway epithelial cells in vitro, we have demonstrated a cause-and-effect relationship between ambient PM10 and allergic asthma in both the induction and exacerbation phases. In addition, we have shown that airway epithelial injury via oxidative stress, with release of interleukin-33, is a likely pathogenetic mechanism in both settings [8, 9]. It is heartening to note the accumulating evidence of convergence between epidemiological studies and experimental work.

Also of considerable interest is the fact that the authors examined the relationship between asthma and exposure to PM10. As CAI et al. correctly point out, particulate matter air pollution can derive from sources other than traffic. Many recent studies have examined relationships to exposure with PM2.5 (which includes so-called fine and ultrafine particles and is primarily traffic-derived) and have thus ignored PM2.5-10 (coarse particles which are included within PM10). We have demonstrated that PM10 may in fact be more injurious to airway epithelium than PM2.5, possibly because of the iron content of coarse particles [10]. The findings of CAI et al., who have demonstrated a relatively large effect for PM10, lend strong support to our earlier suggestion that regulatory and research activities related to the health effects of airborne particulate matter should not focus solely on fine particles.

@ERSpublications

Air pollution by PMio is related to induction of asthma and its exacerbations http://ow.ly/5GPA30aCrC4

Cite this article as: Herbert C, Kumar RK. Ambient air pollution and asthma. Eur Respir J 2017; 49: 1700230 [https://doi.org/10.1183/13993003.00230-2017].

Cristan Herbert and Rakesh K. Kumar

Dept of Pathology, School of Medical Sciences, University of New South Wales, Sydney, Australia.

Correspondence: R. K. Kumar, Dept of Pathology, School of Medical Sciences, University of New South Wales, Sydney, Australia 2052. Email: r.kumar@unsw.edu.au

Received: Feb 012017 | Accepted: Feb 082017

Conflict of interest: Disclosures can be found alongside this article at erj.ersjournals.com

\section{References}

1 Cai Y, Zijlema WL, Doiron D, et al. Ambient air pollution, traffic noise and adult asthma prevalence: a BioSHaRE approach. Eur Respir J 2017; 49: 1502127.

2 Gehring U, Wijga AH, Brauer M, et al. Traffic-related air pollution and the development of asthma and allergies during the first 8 years of life. Am J Respir Crit Care Med 2010; 181: 596-603.

3 Penard-Morand C, Raherison C, Charpin D, et al. Long-term exposure to close-proximity air pollution and asthma and allergies in urban children. Eur Respir J 2010; 36: 33-40.

4 McConnell R, Islam $\mathrm{T}$, Shankardass $\mathrm{K}$, et al. Childhood incident asthma and traffic-related air pollution at home and school. Environ Health Perspect 2010; 118: 1021-1026.

5 Perez L, Declercq C, Iniguez C, et al. Chronic burden of near-roadway traffic pollution in 10 European cities (APHEKOM network). Eur Respir J 2013; 42: 594-605.

6 Weinmayr G, Romeo E, De Sario M, et al. Short-term effects of $\mathrm{PM}_{10}$ and $\mathrm{NO}_{2}$ on respiratory health among children with asthma or asthma-like symptoms: a systematic review and meta-analysis. Environ Health Perspect 2010; 118: 449-457.

7 Spira-Cohen A, Chen LC, Kendall M, et al. Personal exposures to traffic-related air pollution and acute respiratory health among Bronx schoolchildren with asthma. Environ Health Perspect 2011; 119: 559-565. 
8 Herbert C, Siegle JS, Shadie AM, et al. Development of asthmatic inflammation in mice following early-life exposure to ambient environmental particulates and chronic allergen challenge. Dis Model Mech 2013; 6: 479-488.

9 Shadie AM, Herbert C, Kumar RK. Ambient particulate matter induces an exacerbation of airway inflammation in experimental asthma: role of interleukin-33. Clin Exp Immunol 2014; 177: 491-499.

10 Kumar RK, Shadie AM, Bucknall MP, et al. Differential injurious effects of ambient and traffic-derived particulate matter on airway epithelial cells. Respirology 2015; 20: 73-79.

Copyright @ERS 2017 